\title{
Effect of Lameness on Ovarian Activity in Postpartum Holstein Cows*
}

\author{
E. J. Garbarino, ${ }^{1}$ J. A. Hernandez, ${ }^{1}$ J. K. Shearer ${ }^{1}$ C. A. Risco, ${ }^{1}$ and W. W. Thatcher ${ }^{2}$ \\ ${ }^{1}$ College of Veterinary Medicine, Department of Large Animal Clinical Sciences, and \\ ${ }^{2}$ IFAS Department of Animal Sciences, University of Florida, Gainesville, 32610-0136
}

\section{ABSTRACT}

A longitudinal study was conducted to examine the relationship between lameness and delayed ovarian cyclicity during the first $60 \mathrm{~d}$ postpartum and days to first luteal activity during the first $300 \mathrm{~d}$ postpartum in Holstein cows. Two hundred thirty-eight cows from a 600 -cow dairy that calved during a 12 -mo period were used. Cows were classified into 1 of 6 categories of lameness during the first $35 \mathrm{~d}$ postpartum using a locomotion scoring system. Cows were blood-sampled weekly for detection of plasma progesterone concentrations during the first $300 \mathrm{~d}$ postpartum. Cows with delayed resumption of ovarian cyclicity were defined as those with progesterone concentrations consistently $<1 \mathrm{ng} / \mathrm{mL}$ during the first $60 \mathrm{~d}$ postpartum. The null hypothesis that risk of delayed cyclicity is the same in cows classified as nonlame, moderately lame, or lame (after adjusting for potential modifying or confounding effects of loss of body condition and other variables related with delayed cyclicity) was tested using logistic regression. Analysis of results of the study reported here support the hypothesis that lameness is associated with delayed ovarian activity in Holstein cows during the early postpartum period. Cows classified as lame had 3.5 times greater odds of delayed cyclicity, compared with cows classified as nonlame. Attributable proportion analysis indicated that delayed ovarian cyclicity in lame cows would be reduced by $71 \%$, if lameness had been prevented.

(Key words: lameness, ovarian activity, postpartum, Holstein)

Abbreviation key: $\mathbf{M E}=$ mature equivalent, $\mathbf{O R}=$ odds ratio, $\mathbf{P}_{4}=$ progesterone .

\section{INTRODUCTION}

Lameness is one of the top 3 health problems that cause premature culling of dairy cows in the United

\footnotetext{
Received February 12, 2004.

Accepted August 19, 2004.

Corresponding author: J. A. Hernandez; e-mail: hernandezj@mail. vetmed.ufl.edu.

*This study was supported in part by the USDA National Research Initiative Competitive Grants Program (Grant No. FLAV-CO-00227) and the Florida Dairy Check-Off Program, and the UF College of Veterinary Medicine.
}

States. The National Animal Health Monitoring System Dairy 2002 study reported that lameness was the reason for culling $16 \%$ of dairy cows sent to slaughter (NAHMS, 2002). Overall, 10\% of cows were reported affected with lameness in the previous 12 mo (NAHMS, 2002). The economic importance of lameness is reportedly attributable to cost of treatment and control methods (Shearer and Elliot, 1998; Shearer et al., 1998; Hernandez et al., 1999; Hernandez et al., 2000; Moore et al., 2001), impaired reproductive performance (Lucey et al., 1986; Lee et al., 1989; Sprecher et al., 1997; Hernandez et al., 2001; Melendez et al., 2003), decreased milk yield (Warnick et al., 2001; Green et al., 2002; Hernandez et al., 2002), increased risk of culling (Collick et al., 1989; Sprecher et al., 1997), and decreased carcass value of culled cows (Van Arendonk et al., 1984). In addition, because of the pain, discomfort, and high incidence of lameness in dairy cows, this disorder is an animal-welfare issue of concern.

Delayed ovarian cyclicity in the preservice postpartum period is a common ovarian dysfunction in dairy cows. In studies conducted in commercial dairy herds in Belgium, Canada, Japan, and the United States, for instance, 20 to $33 \%$ of study cows were reported to have delayed ovarian activity during the first 50 to $60 \mathrm{~d}$ postpartum (Staples et al., 1990; Etherington et al., 1991; Nakao et al., 1992; Opsomer et al., 1998, 2000; Moreira et al., 2001). Late resumption of ovarian activity postpartum has a detrimental effect on reproductive performance in dairy cows (Thatcher and Wilcox, 1973; Stevenson and Call, 1983; Lucy et al., 1992). Cows ovulating earlier postpartum have fewer services per conception and a shorter calving-to-conception interval (Lucy et al., 1992). Minimizing the interval from calving to first ovulation provides ample time for completion of multiple ovarian cycles before insemination, which in turns improves conception rates (Butler and Smith, 1989). Losses in body condition, puerperal disturbances, and ketosis have been identified as risk factors significantly associated with delayed ovarian cyclicity in dairy cows (Opsomer et al., 2000).

Previous studies have established an association between lameness and impaired reproductive performance (e.g., a prolonged calving-to-conception interval) (Lucey et al., 1986; Collick et al., 1989; Sprecher et 
al., 1997; Hernandez et al., 2001), but the relationship between lameness and ovarian activity in dairy cows has not been investigated using objective research methods. Results of previous studies in Florida suggest that as cows experience increasing positive energy status, there is increased ovarian follicular activity leading to early return to ovulation (Staples et al., 1990; Lucy et al., 1992). As energy status becomes more positive for cows in early postpartum, diameter of the largest follicle increases, the number of double ovulations increases, and time for detection of the first corpus luteum decreases (Lucy et al., 1991). These changes in follicle numbers and size and the number of ovulations are thought to be caused by increases in luteinizing hormone, insulin, GH, insulin-like growth factor-1, and possibly other yet-to-be-determined compounds that are activated by an improved energy status (Beam and Butler, 1998).

Clinical observations by veterinarians and dairy farmers in Florida suggest that lameness has a detrimental effect on ovarian activity in lactating dairy cows. Veterinarians and dairy farmers prefer to avoid the use of synchronization and timed-insemination protocols in lame cows because it is known that lame cows experience a more severe loss of body condition (Tranter and Morris, 1991), spend less time eating (Hassall, 1993), and are less likely to be cyclic, compared with nonlame cows, until lameness has been resolved. We hypothesized that because lame cows experience a more pronounced loss in body condition (hence a prolonged state of negative energy balance) during the early postpartum period, they are at higher risk of delayed ovarian cyclicity than nonlame cows. Under field conditions, evidence of corpus luteum function can be determined by monitoring plasma progesterone $\left(\mathbf{P}_{\mathbf{4}}\right)$ concentrations weekly during lactation, before and after diagnosis of lameness in dairy cows. The objectives of the study reported here were to examine the relationship between lameness and delayed resumption of ovarian cyclicity during the first $60 \mathrm{~d}$ postpartum and days to first luteal phase during the first $300 \mathrm{~d}$ postpartum in Holstein cows.

\section{MATERIALS AND METHODS}

\section{Cows and Herd Management}

Cows in this study were from a high-producing dairy herd (rolling herd average milk production, $12,000 \mathrm{~kg}$ ) of approximately 600 Holstein cows located in Florida. This herd was selected for the study based on a history of lameness, quality of veterinary records, and willingness of the owner to participate in the study. Cows were milked and fed a TMR 3 times/d. Cows were housed in lots equipped with sprinklers, fans, and shade cloths over the feed bunks to reduce effects of heat stress. In this farm, most of the cows are enrolled in a program to presynchronize the stage of the estrous cycle followed by synchronization of ovulation (Moreira et al., 2001). This program involves the use of 2 injections of $\mathrm{PGF}_{2 \alpha}$; the first injection is given at 30 to $35 \mathrm{~d}$ postpartum and the second at 44 to $49 \mathrm{~d}$ postpartum. Fourteen days later (58 to $63 \mathrm{~d}$ postpartum), cows in this group are injected with $\mathrm{GnRH}, 7 \mathrm{~d}$ later with $\mathrm{PGF}_{2 \alpha}$, and $2 \mathrm{~d}$ later with a second injection of GnRH followed by a timed AI 16 to $18 \mathrm{~h}$ later (68 to $73 \mathrm{~d}$ postpartum).

\section{Study Design}

This study was designed as a longitudinal study. Sample size calculations were made based on our estimate of the number of cows affected with delayed cyclicity increasing from $10 \%$ in nonlame cows to $30 \%$ in lame cows (type I error $=0.05$; type II error $=0.20$ ). Five hundred and sixty-three Holstein cows that calved from June 1, 2002, until May 31, 2003, were considered for inclusion in the study. Two hundred and fifty-three (45\%) cows identified with an even ear-tag number were enrolled in the study as they calved (instead of cows randomly selected) to overcome logistical identification procedures and to reduce disruption of routine veterinary medical and management procedures at the study farm (it is easier to identify cows with even ear-tag numbers than cows with either even or odd numbers, as it would be expected if a random selection process had been used). Cows were classified into 1 of 6 categories of lameness during the first $35 \mathrm{~d}$ postpartum using a locomotion scoring system. Cows were blood-sampled weekly for detection of plasma $\mathrm{P}_{4}$ concentrations during the first $300 \mathrm{~d}$ postpartum. Risk of delayed cyclicity during the first $60 \mathrm{~d}$ postpartum and days to first luteal phase during the first $300 \mathrm{~d}$ postpartum were compared between cows classified as nonlame, moderately lame, or lame. In the analyses, lame cows were those that had lameness prior to resumption of ovarian cyclicity.

\section{Data Collection}

Using farm records, the following data were collected for each cow: lactation number, calving date, calving season (winter months: Jan-Apr and Oct-Dec; summer months: May-Sep), dystocia (yes, no), retained placenta (yes, no), metritis (yes, no), mastitis (yes, no), ketosis (yes, no), body condition score at calving using a scale of 1 to 5 with 0.25 increments (Edmonson et al., 1989), change in body condition score in the first 47 to $53 \mathrm{~d}$ postpartum, use of $\mathrm{PGF}_{2 \alpha}$ (Lutalyse, Pharmacia, Kalamazoo, MI) before resumption of ovarian activity (yes, no), and 305-d mature equivalent (ME) milk yield. Cows 
Table 1. Frequency distribution of cows classified as lame or nonlame using a locomotion scoring system. ${ }^{1}$

\begin{tabular}{|c|c|c|c|}
\hline $\begin{array}{l}\text { Locomotion } \\
\text { score }\end{array}$ & $\begin{array}{l}\text { Clinical } \\
\text { description }\end{array}$ & Assessment criteria & $\begin{array}{l}\text { No. of cows }(\%) \\
(\text { Total } \mathrm{n}=238)\end{array}$ \\
\hline 0 & Normal & $\begin{array}{l}\text { The cow stands and walks with a level-back } \\
\text { posture. Its gait is normal. }\end{array}$ & $3(1)$ \\
\hline 1 & Barely lame & $\begin{array}{l}\text { The cow stands with a level-back posture but } \\
\text { develops an arched-back posture while walking. } \\
\text { Its gait remains normal. }\end{array}$ & $17(7)$ \\
\hline 2 & Mildly lame & $\begin{array}{l}\text { An arched-back posture is evident while } \\
\text { standing and walking. Cow's gait seems normal. }\end{array}$ & $76(32)$ \\
\hline 3 & Moderately lame & $\begin{array}{l}\text { An arched-back posture is evident while } \\
\text { standing and walking. Cow's gait is affected and } \\
\text { is best described as short strides with one or } \\
\text { more limbs. }\end{array}$ & $101(42)$ \\
\hline 4 & Lame & $\begin{array}{l}\text { An arched-back posture is always evident and } \\
\text { gait is best described as one deliberate step at a } \\
\text { time. The cow favors one or more limbs/feet. }\end{array}$ & $41 \quad(17)$ \\
\hline 5 & Severely lame & $\begin{array}{l}\text { In addition, the cow demonstrates an inability or } \\
\text { extreme reluctance to bear weight on one or } \\
\text { more limbs/feet. }\end{array}$ & $0(0)$ \\
\hline
\end{tabular}

${ }^{1}$ Sprecher et al. (1997) with modifications.

with retained fetal membranes were cows that failed to expel fetal membranes within $24 \mathrm{~h}$ after parturition. Cows with metritis were cows with fetid discharge from the uterus. Cows with mastitis were cows with a deviation from milk conductivity by the Afimilk system and later confirmed by foremilk stripping by the attending farm worker. Cows with ketosis were cows diagnosed with ketonuria using urine strips (Ketostix) based on sodium nitroprusside that detects acetoacetate. The range of BCS was from 1 (severe undercondition - emaciated) to 5 (severe overcondition), where a score of 3 was assigned to cows observed with a well-balanced covered frame. The change in BCS was calculated by subtracting the score at calving from that at 47 to 53 d postpartum. For loss of body condition, we chose the score at 47 to $53 \mathrm{~d}$ postpartum because lameness exposure was measured during the first $35 \mathrm{~d}$ postpartum and because cows are at high risk of reduced ovarian activity during the first and second month after calving (Opsomer et al., 2000). From DHIA records, projected 305-d ME milk yield data were collected based on production at $60 \mathrm{~d}$ postpartum. Levels of milk yield were defined as low (5,530 to $10,619 \mathrm{~kg} 305-\mathrm{d} \mathrm{ME})$, medium (10,620 to $12,978 \mathrm{~kg} 305-\mathrm{d} \mathrm{ME})$, and high $(12,979$ to $15,137 \mathrm{~kg}$ 305-d ME), based on the frequency of distribution (first, second and third, and fourth quartiles, respectively).

\section{Diagnosis of Lameness}

During the first $35 \mathrm{~d}$ postpartum, study cows were examined weekly (Tuesday) for diagnosis of lameness by using a locomotion scoring system described by Sprecher et al. (1997) with modifications (Table 1). This system was tested weekly over a 2-mo period (AprilMay 2002) in all lactating cows, before enrollment of the first cow in the study (June 1, 2002). After testing the locomotion scoring system in the study herd, a new category was added to include cows that were observed with an arched-back posture that was evident while standing and walking, but with a normal gait (score = 2 , mildly lame). Cows were observed and scored by the same veterinarian as they walked out of the washing pen to the holding area before milking. Cows with a locomotion score of 4 or 5 were further examined on a tilt table for diagnosis and treatment of lameness, noting lesions observed and date of occurrence. Lame cows with claw lesions had white line lesions or sole ulcers and were treated with corrective foot trimming techniques (Shearer and van Amstel, 2001). Lame cows with subacute laminitis were those with yellow and red discoloration of the sole and white line, and in most cases, they had thin soles and were sensitive at examination with hoof testers (Toussaint-Raven, 1989). Lame cows with interdigital dermatitis were those with inflammation confined to the epidermis and in some cases, hyperkeratosis, which creates a roughened appearance to the interdigital skin (Blowey, 1994); a fetid serous exudate could be present, and there was mild sensitivity to pressure. This condition was frequently accompanied by cracks in the heel, heel horn erosions, with potential under-running of the heel horn (Berry, 2001).

\section{Collection of Blood Samples and Detection of Plasma $\mathrm{P}_{4}$ Concentrations}

Cows were blood-sampled and scored for body condition (Edmonson et al., 1989) weekly (Thursday) for de- 
tection of plasma $\mathrm{P}_{4}$ concentrations during the first 300 $\mathrm{d}$ postpartum. Cows were blood-sampled via coccygeal venipuncture using Vacutainer collection tubes containing $\mathrm{K}_{3}$ EDTA (Becton Dickinson, Franklin Lakes, NJ). Blood samples were refrigerated until and during transportation to a laboratory at the University of Florida where they were centrifuged for $20 \mathrm{~min}$ at 3000 rpm at room temperature for plasma harvest. Plasma samples were frozen at $-20^{\circ} \mathrm{C}$ until tested for $\mathrm{P}_{4}$ concentrations (Coat-A-Count radioimmunoassay).

Accuracy of assay procedures was determined by measuring known quantities of exogenous progesterone $(0.625,1.25,2.5$, and $5.0 \mathrm{ng} / \mathrm{mL})$ in cow's plasma in 7 different assays. Recovery of added (x) vs. measured (y) $\mathrm{P}_{4}$ concentrations were described by linear regression $\left(y=0.57+0.93 \mathrm{x} ; \mathrm{R}^{2}=0.89\right)$. The regression intercept value $(0.57 \mathrm{ng} / \mathrm{mL})$ represented original $\mathrm{P}_{4}$ concentrations measured in a plasma pool before addition of exogenous masses.

The radioactive displacement curve for different volumes of plasma pool containing $8 \mathrm{ng} / \mathrm{mL}$ of $\mathrm{P}_{4}$ (i.e., $0.1,0.25,0.5,1.0,2.0,5.0,10.0$, and $20.0 \mathrm{ng} / \mathrm{mL}$ ) were examined as 2 separate logit plots ( $\mathrm{y}=\ln$ of Bound/ Free and $\mathrm{x}=\log _{10}$ of $\mu \mathrm{L}$ or $\mathrm{ng} / \mathrm{mL}$ ) that were linear. Heterogeneity of regression was examined by determining whether fitting 2 separate linear regressions was a significantly better fit than fitting a single pooled linear regression. The linear regression lines for plasma and $\mathrm{P}_{4}$ standards were not heterogeneous, indicating that the slopes were not different $\left(\mathrm{y} P=0.60\right.$ to $1.44 \mathrm{x}, \mathrm{R}^{2}=$ $0.99 ; \mathrm{ys}=0.21$ to $1.61 \mathrm{x}, \mathrm{R}^{2}=0.99$; where yp and ys $=$ $\ln \mathrm{B} / \mathrm{F}, \mathrm{x}=\log _{10}$ of assay volume or $\log _{10}$ standard $\mathrm{P}_{4}$ concentrations, respectively).

Coefficients of variation were calculated from a reference sample (luteal phase) and duplicated samples obtained from all assays. Duplicated plasma concentrations of $\mathrm{P}_{4}$ were categorized into high $(\geq 3.0 \mathrm{ng} / \mathrm{mL} ; \mathrm{n}=$ 359 ), medium ( $\geq 1.0$ and $<3.0 \mathrm{ng} / \mathrm{mL} ; \mathrm{n}=128$ ), and low $(\geq 0.3$ and $<1.0 \mathrm{ng} / \mathrm{mL} ; \mathrm{n}=52)$, and the coefficients of variation were $12.4,12.4$, and $14.2 \%$, respectively. Inter- and intraassay coefficients of variation for the luteal phase reference sample were 8.9 and $8.34 \%$, respectively.

\section{Outcomes}

The main outcome of interest was resumption of ovarian cyclicity during the first $60 \mathrm{~d}$ postpartum. Cows with evidence of normal ovarian cyclicity during the first $60 \mathrm{~d}$ postpartum were those with: (1) weekly plasma $\mathrm{P}_{4}$ concentrations $>1 \mathrm{ng} / \mathrm{mL}$ for 2 or 3 consecutive samples and followed by a decline in $\mathrm{P}_{4}$; or (2) $\mathrm{P}_{4}$ concentration $>1 \mathrm{ng} / \mathrm{mL}$ followed by a marked decrease after a $\mathrm{PGF}_{2 \alpha}$ injection and this followed by an increase in $\mathrm{P}_{4}$ concentration. Cows with a delayed resumption of ovarian cyclicity were those with concentrations of $\mathrm{P}_{4}$ consistently $<1 \mathrm{ng} / \mathrm{mL}$ during the first $60 \mathrm{~d}$ post partum (Staples et al., 1990). A follow-up period of 60 d postpartum was chosen because an Ovsynch protocol was initiated at 58 to $63 \mathrm{~d}$ postpartum, which was the end of the voluntary waiting period in the study farm. A secondary outcome of interest was time (d) to first luteal phase, which was defined as the first rise in $\mathrm{P}_{4}$ above $1 \mathrm{ng} / \mathrm{mL}$ during the first $300 \mathrm{~d}$ postpartum.

\section{Statistical Analyses}

The null hypothesis that risk of delayed cyclicity is the same in cows classified as nonlame, moderately lame, or lame was tested by using logistic regression. In the analysis, nonlame cows were those with a score of 3 for 1 wk only or scores of $\leq 2$. The rationale for classifying cows with a score $\leq 2$ as nonlame in the analysis was that their gait seemed normal. Cows classified as moderately lame were those with a score of 3 on 2 consecutive weeks to reduce the risk of misclassification. Lame cows were those classified at least once with a locomotion score $=4$ or 5 . Additional independent variables (lactation number, calving season, milk yield, dystocia, retained placenta, metritis, mastitis, ketosis, $\mathrm{BCS}$ at calving and loss of body condition, use of $\mathrm{PGF}_{2 \alpha}$ ) were examined in the analysis to address possible modifying or confounding effects that these factors might have had on risk of delayed cyclicity. We examined the association between body-condition loss of 0.50 and 0.75 points and delayed cyclicity. Because the associated odds ratio (OR) was similar, we used the BCS loss of 0.75 in the analysis. We did not examine the association between a BCS loss of $\geq 1.0$ point, because the frequency of cows in that category was low $(n=9)$. Stepwise forward regression was used, and a variable had to be significant at the 0.20 level before it could enter the model. A variable remained in the model when its significance level was $P<0.10$. Variables for lactation number and calving season were forced into the model because they can affect ovarian activity (Stevenson and Britt, 1979; Fonseca et al., 1983; Savio et al., 1990; Lucy et al., 1992; Jonsson et al., 1997; Moreira et al., 2001). In the final model, adjusted OR and 95\% confidence intervals were reported. In this study, the OR was used as an epidemiologic measure of association between a variable (i.e., lameness) and the outcome of interest (i.e., delayed cyclicity). In each variable, the reference category had an $\mathrm{OR}=1$. An adjusted $\mathrm{OR}>1.0$ indicates that the probability of delayed cyclicity increased, compared with cows in the reference category. The model's goodness of fit was explored using the Hosmer-Lemeshow goodness of fit $\chi^{2}$ statistic and standardized residu- 
als. The attributable proportion was estimated as (OR -1 )/OR and interpreted to represent the proportion of lame cows that experienced delayed ovarian cyclicity because of lameness (Martin et al., 1987).

The null hypothesis that number of days postpartum to first luteal phase did not differ among groups of cows classified as nonlame, moderately lame, or lame was tested by use of the Kruskal-Wallis nonparametric test (because the dependent variable failed to meet assumptions of parametric testing) and multiple ANOVA for the dependent variable of days to first luteal phase (ranked data) while simultaneously adjusting for variables related to ovarian cyclicity (i.e., lactation number, calving season, ketosis, and milk yield). Significance was set at $P \leq 0.05$.

\section{RESULTS}

\section{Risk of Delayed Cyclicity}

All 253 cows enrolled in the study were followed up successfully during the 60-d study period. Two hundred and thirty-eight $(94 \%)$ cows met the criteria for ovarian cyclicity and were used in this study. A total of 101 of $238(42 \%)$ cows were classified as moderately lame (locomotion score $=3$ ) and $41(17 \%)$ as lame (score = 4). The mean number of days postpartum when cows were classified as lame was $15 \mathrm{~d}$. The most common lesions observed in lame cows ( score $=4$ ) were subacute laminitis $(26 / 41=63 \%)$, and claw lesions such as sole ulcers and white line disease $(9 / 41=22 \%)$. The overall incidence of delayed cyclicity was $11 \%$. The incidence of delayed cyclicity was higher in cows classified as moderately lame $(14 / 101 ; 14 \%)$ or lame $(7 / 41 ; 17 \%)$, compared with nonlame cows $(6 / 96 ; 6 \%)$. In the univariable analysis, cows classified as lame had 3.09 times greater odds of delayed cyclicity, compared with nonlame cows $(\mathrm{OR}=3.09 ; 95 \% \mathrm{CI}=0.97$ to 9.83$)(P=0.05)$ (Table 2). In addition, cows classified as moderately lame tended to have greater odds of delayed cyclicity, compared with nonlame cows $(\mathrm{OR}=2.41 ; 95 \% \mathrm{CI}=0.90$ to $6.55 ; P=0.08$ ).

Cows treated with $\mathrm{PGF}_{2 \alpha}$ (before they were recognized as cycling by $\mathrm{P}_{4}$ analysis) were identified. Some cows were treated with $\mathrm{PGF}_{2 \alpha}$ for a uterine condition or as part of a synchronization program, but all cows were treated before they started cycling. Results of the univariable analysis revealed that treatment with $\mathrm{PGF}_{2 \alpha}$ was not associated with delayed cyclicity $(\mathrm{OR}=$ $0.8 ; 95 \% \mathrm{CI}=0.38$ to $1.95 ; P=0.70$ ) (Table 2 ). Thus, this variable was not included in the multivariable analysis.

In the multivariable analysis, lameness, lactation number, season, ketosis, and milk yield were retained in the final modeling process (Table 3). Addition of 2way interaction terms did not contribute to the final model for risk of delayed cyclicity, and these terms were removed from the model. Cows classified as lame had 3.50 times greater odds of delayed cyclicity, compared with nonlame cows $(\mathrm{OR}=3.50 ; 95 \% \mathrm{CI}=1.00$ to 12.21 ; $P=0.04$ ). The attributable proportion of cows that experienced delayed ovarian cyclicity associated with lameness was 0.71 . In addition, cows classified as moderately lame tended to have greater odds of delayed cyclicity, compared with nonlame cows $(\mathrm{OR}=2.14 ; 95 \% \mathrm{CI}=0.74$ to $6.14 ; P=0.15)$. Finally, ketosis was, by itself, a risk factor for delayed resumption of ovarian cyclicity $(\mathrm{OR}=$ $2.76 ; 95 \% \mathrm{CI}=1.08$ to $7.06 ; P=0.03)$. The HosmerLemeshow goodness-of-fit statistic was 2.45 (8 degrees of freedom; $P=0.96$ ) and indicated that the overall fit of the model was very good. Examination of standardized residuals revealed that cows with the 3 largest residuals may have experienced delayed cyclicity due to mechanisms not included in the final model. Two cows, calved in the winter, were in their first lactation and were classified as nonlame, nonketotic, and medium-milk producing cows. The third cow, calved in the summer, was in its first lactation and was classified as a moderately lame, nonketotic, and high-milk producing cow. When those 3 cows were removed from the model based on the full data set and the model was refit to the remaining study cows, the adjusted OR for cows classified as lame or moderately lame moved away from the null (i.e., $\mathrm{OR}=6.19,95 \% \mathrm{CI}=1.51$ to $25.30, P=0.01$ and $\mathrm{OR}=2.94,95 \% \mathrm{CI}=0.86$ to $10.05, P=0.08$, respectively). This suggests that the model based on the full data set provided conservative estimates of the effects of lameness on delayed cyclicity.

\section{Days to First Luteal Phase}

Overall, the median interval from calving to first luteal phase in the study population was $31 \mathrm{~d}$. Intervals were longer $(P \leq 0.05)$ in cows classified as lame (median $=36 \mathrm{~d}$; range $=17$ to $97 \mathrm{~d}$ ) or moderately lame (median $=32 \mathrm{~d}$; range $=4$ to $146 \mathrm{~d}$ ), compared with nonlame cows $($ median $=29 \mathrm{~d}$; range $=2$ to $172 \mathrm{~d}$ ).

\section{DISCUSSION}

Analysis of results of the study reported here support the hypothesis that lameness has a detrimental effect on ovarian activity in Holstein cows during the early postpartum period. Cows classified as lame (score $=4)$ had 3.5 times greater odds of delayed cyclicity than nonlame cows (score $\leq 2)(\mathrm{OR}=3.50 ; 95 \% \mathrm{CI}=1.00$ to $12.21 ; P=0.04$ ). Attributable proportion analysis indicated that delayed ovarian cyclicity in lame cows would be reduced by $71 \%$ if lameness had been prevented. This inference is further supported by the fact 
Table 2. Descriptive statistics and unadjusted odds ratios (OR) for risk of delayed cyclicity in postpartum Holstein cows.

\begin{tabular}{|c|c|c|c|c|c|}
\hline Variable & $\begin{array}{l}\text { Delayed cyclicity } \\
\text { Yes } \\
\mathrm{n}=27\end{array}$ & $\begin{array}{l}\text { Delayed cyclicity } \\
\text { No } \\
n=211\end{array}$ & OR & $95 \% \mathrm{CI}$ & $P$ \\
\hline & No. of cows (\%) & No. of cows (\%) & & & \\
\hline \multicolumn{6}{|l|}{ Lameness group } \\
\hline Locomotion score $\leq 2$ & $6(22)$ & $90(43)$ & 1.00 & Reference & NA \\
\hline 3 & $14(52)$ & $87(41)$ & 2.41 & $0.90-6.55$ & 0.08 \\
\hline 4 & $7(26)$ & $34(16)$ & 3.09 & $0.97-9.83$ & 0.05 \\
\hline \multicolumn{6}{|l|}{ Lactation number } \\
\hline 1 & $10(37)$ & $77(36)$ & 1.00 & Reference & NA \\
\hline$\geq 2$ & $17(63)$ & $134(64$ & 0.98 & $0.43-2.23$ & 0.95 \\
\hline \multicolumn{6}{|l|}{ Season } \\
\hline Winter & $18(67)$ & $123(58)$ & 1.00 & Reference & NA \\
\hline Summer & $9(33)$ & $88(42)$ & 0.70 & $0.30-1.62$ & 0.40 \\
\hline \multicolumn{6}{|l|}{ Milk yield } \\
\hline Low & $9(33)$ & $50(24)$ & 1.05 & $0.43-2.54$ & 0.91 \\
\hline Medium & $16(59)$ & $102(48)$ & 1.00 & Reference & NA \\
\hline High & $2(8)$ & $56(27)$ & 0.22 & $0.05-0.96$ & 0.04 \\
\hline \multicolumn{6}{|l|}{ Dystocia } \\
\hline No & $20(74)$ & $163(77)$ & 1.00 & Reference & NA \\
\hline Yes & $3(11)$ & $17(8)$ & 1.44 & $0.39-5.34$ & 0.58 \\
\hline \multicolumn{6}{|l|}{ Retained placenta } \\
\hline No & $23(85)$ & $181(86)$ & 1.00 & Reference & NA \\
\hline Yes & $4(15)$ & $30(14)$ & 1.05 & $0.34-3.24$ & 0.93 \\
\hline \multicolumn{6}{|l|}{ Metritis } \\
\hline No & $16(59)$ & $132(63)$ & 1.00 & Reference & NA \\
\hline Yes & $11(41)$ & $79(37)$ & 1.15 & $0.51-2.59$ & 0.73 \\
\hline \multicolumn{6}{|l|}{ Mastitis } \\
\hline No & $25(93)$ & $174(82)$ & 1.00 & Reference & NA \\
\hline Yes & $2(7)$ & $37(18)$ & 0.38 & $0.09-1.64$ & 0.19 \\
\hline \multicolumn{6}{|l|}{ Ketosis } \\
\hline No & $18(67)$ & $177(84)$ & 1.00 & Reference & NA \\
\hline Yes & $9(33)$ & $34(16)$ & 2.60 & $1.08-6.28$ & 0.03 \\
\hline \multicolumn{6}{|l|}{ BCS at calving } \\
\hline$<2.75$ & $3(11)$ & $34(16)$ & 0.68 & $0.19-2.40$ & 0.55 \\
\hline $2.75-3.5$ & $20(74)$ & 151 & 1.00 & Reference & NA \\
\hline$>3.5$ & $4(15)$ & $26(12)$ & 1.28 & $0.40-4.10$ & 0.67 \\
\hline \multicolumn{6}{|l|}{ BCS change $(0.75)$} \\
\hline No & $20(74)$ & $173(82)$ & 1.00 & Reference & NA \\
\hline Yes & $7(26)$ & $38(18)$ & 1.59 & $0.63-4.03$ & 0.32 \\
\hline \multicolumn{6}{|l|}{ Use of $\mathrm{PGF}_{2 \alpha}$} \\
\hline No & $17(63)$ & $125(59)$ & 1.0 & Reference & NA \\
\hline Yes & $10(37)$ & $86(41)$ & 0.86 & $0.38-1.95$ & 0.70 \\
\hline
\end{tabular}

that the interval from calving to first luteal phase was longer $(P<0.05)$ in lame cows (median $=36 \mathrm{~d})$, compared with nonlame cows $(29 \mathrm{~d})$. To our knowledge, only one previous study has examined the relationship between lameness and ovarian activity. In a study conducted in 335 dairy cows on 6 high-producing dairy herds in Belgium, cows diagnosed with clinical mastitis, severe lameness, or pneumonia by farmers were at higher risk of delayed cyclicity, compared with cows classified as clinically healthy (Opsomer et al., 2000). However, the actual number of cows affected with clinical mastitis, severe lameness, or pneumonia was not reported.

Although cows classified as moderately lame (score = 3 ) in the current study did not have significantly greater odds of delayed cyclicity than nonlame cows, the relationship was numerically in the same direction as for lame cows with a score of 4 . Because median intervals from calving to first luteal phase were progressively longer with increasing degree of lameness, intervention to attenuate lameness at early stages is important. Without the use of a locomotion scoring system, moderately lame cows may not be recognized as lame by veterinarians or farm workers. Preventive measures such as examination of cows' feet and use of corrective foot trimming techniques should be targeted at moderately lame cows, as they represented $42 \%$ of the study population.

The incidence of cows classified as moderately lame ( score $=3$ ) and lame (score $=4$ ) during the first $35 \mathrm{~d}$ postpartum was 42 and $17 \%$, respectively. In a previous study conducted in 66 dairy cows on one farm in Michigan (Sprecher et al., 1997), a 5-point locomotion scoring 
Table 3. Final logistic regression model for risk of delayed cyclicity in postpartum Holstein cows.

\begin{tabular}{|c|c|c|c|}
\hline Variable & $\begin{array}{l}\text { Adjusted } \\
\text { odds } \\
\text { ratio }\end{array}$ & $\begin{array}{l}95 \% \\
\text { confidence } \\
\text { interval }\end{array}$ & $P$ value \\
\hline \multicolumn{4}{|l|}{ Lameness group } \\
\hline Locomotion score $\leq 2$ & 1.00 & Reference & $\mathrm{NA}^{1}$ \\
\hline 3 & 2.14 & $0.74-6.14$ & 0.15 \\
\hline 4 & 3.50 & $1.00-12.21$ & 0.04 \\
\hline \multicolumn{4}{|l|}{ Lactation number } \\
\hline 1 & 1.00 & Reference & NA \\
\hline$\geq 2$ & 1.23 & $0.50-2.33$ & 0.65 \\
\hline \multicolumn{4}{|l|}{ Season } \\
\hline Winter & 1.00 & Reference & NA \\
\hline Summer & 0.95 & $0.38-2.33$ & 0.90 \\
\hline \multicolumn{4}{|l|}{ Ketosis } \\
\hline No & 1.00 & Reference & NA \\
\hline Yes & 2.76 & $1.08-7.06$ & 0.03 \\
\hline \multicolumn{4}{|l|}{ Milk yield } \\
\hline Low & 0.99 & $0.39-2.52$ & 0.98 \\
\hline Medium & 1.00 & Reference & NA \\
\hline High & 0.21 & $0.05-0.98$ & 0.04 \\
\hline
\end{tabular}

${ }^{1} \mathrm{NA}=$ Not applicable

system was used for diagnosis of lameness. In the Michigan study, 27 (49\%) cows and $14(24 \%)$ cows were classified as moderately lame and lame, respectively. Results from that study are difficult to directly compare with results of the present study because the 5-point system used in the Michigan study did not include cows with an arched-back posture that was evident while standing and walking, but with normally appearing gaits. In our study, such cows were classified as mildly lame ( score $=2 ; \mathrm{n}=76$, or $32 \%$ ). The possibility that cows classified as mildly lame (score $=2$ ) in our study perhaps should have been classified as moderately lame (score $=3$ ) is not likely, as the incidence of delayed cyclicity was lower in cows with score $=2(3 / 76$ or $4 \%)$, compared with cows with a score $=3(14 / 101$ or $14 \%)$. If cows with a locomotion score $=2$ were misclassified, we would have expected an incidence of delayed cyclicity similar to that observed in cows classified with a locomotion score $=3$.

Although we established an association between lameness and delayed ovarian cyclicity, we failed to identify loss of body condition (or a modifying effect of lameness and loss of body condition) as a significant risk factor associated with delayed cyclicity. A loss in BCS $\geq 0.75$ points in the first $50 \mathrm{~d}$ postpartum did not significantly delay cyclicity, compared with cows that loss body condition $<0.75$ points $(\mathrm{OR}=1.59 ; 95 \% \mathrm{CI}=$ 0.63 to $4.03 ; P=0.32$ ). The observed incidence of delayed cyclicity in the study population was low (11\%), compared with other studies (23 to 29\%) reported in the literature (Humboldt and Thibier, 1980; Bartlett et al., 1987; Staples et al., 1990), creating a sample size limitation. Among 335 dairy cows in Belgium, cows losing more in body condition during the first and second month after calving were at higher risk of delayed cyclicity (Opsomer et al., 2000).

In our study, ketosis was, by itself, a risk factor for delayed resumption of ovarian cyclicity $(\mathrm{OR}=2.76 ; 95 \%$ $\mathrm{CI}=1.08$ to $7.06 ; P=0.03$ ). This result is in agreement with a study conducted in 84 dairy cows on 8 farms in Switzerland (Reist et al., 2000), where blood serum and milk ketone body concentrations during the first $6 \mathrm{wk}$ postpartum were higher in cows classified as late responders (i.e., cows started postpartum ovarian cyclicity after $30 \mathrm{~d}$ ) than in early responders, with no significant differences in BCS between groups. It is possible that lameness and ketosis may additionally interact with each other to affect risk of delayed cyclicity, but sample size was too small in the present study to adequately detect such an interaction. Lameness can depress DM intake (Hassall et al., 1993; Galindo and Broom, 2002) resulting in negative energy balance. It is well accepted that negative energy balance contributes to increased ketone body formation and delays the onset of ovarian activity (Reist et al., 2000). A negative energy balance postpartum not only contributes to increase ketogenesis, but also delays the onset of ovarian cyclicity, especially if energy deficiency is prolonged (Butler and Smith, 1989; Staples et al., 1990; Lucy et al., 1992). Furthermore, results of the study reported here revealed that the risk of delayed cyclicity was lower in high-milk producing cows, compared with medium- or low-milk producing cows. Results of previous studies suggest that low-milk producing cows are associated with inferior DMI, a more negative energy balance, and are less likely to restore ovarian activity during the first $63 \mathrm{~d}$ postpartum, compared with high-milk producing cows (Staples et al., 1990; Lucy et al., 1992).

\section{CONCLUSION}

Analysis of results of the study reported here supports the hypothesis that lameness has a detrimental effect on ovarian activity in Holstein cows during the early postpartum period. The locomotion scoring system used in this study is a useful management tool that veterinarians and dairy farmers can adopt for early detection of lameness in dairy cows.

\section{ACKNOWLEDGMENTS}

The authors thank Nelly Amador, Julie Oakley, Marie-Joelle Thatcher, and Shawn Ward for technical assistance, and Condale Dairy for allowing the use of study cows and for their valuable assistance throughout the study. 


\section{REFERENCES}

Bartlett, P. C., J. Kirk, P. Coe, J. Marteniuk, and E. C. Mather. 1987. Descriptive epidemiology of anestrus in Michigan Holstein-Friesian cattle. Theriogenology 87, 27:459-476.

Beam, S. W., and W. R. Butler. 1998. Energy balance, metabolic hormones, and early postpartum follicular development in dairy cows fed prilled lipid. J. Dairy Sci. 81:121-131.

Berry, S. L. 2001. Interdigital dermatitis. Pages 134-135 in Veterinary Clinics of North America: Food Animal Practice. Vol. 17. D. Anderson, ed. Saunders, Philadelphia, PA.

Blowey, R. W. 1994. Interdigital causes of lameness. Pages 142 154 in Proc. of the 8th International Symposium on Disorders of the Ruminant Digit. Banff, Canada.

Butler, W. R., and R. D. Smith. 1989. Interrelationships between energy balance and postpartum reproductive function in dairy cattle. J. Dairy Sci. 72:767-783.

Collick, D. W., W. R. Ward, and H. Dobson. 1989. Associations between types of lameness and fertility. Vet. Rec. 125:103-106.

Edmonson, A. J., I. J. Lean, L. D. Weaver, T. Farver, and G. Webster. 1989. A body condition scoring chart for Holstein dairy cows. J. Dairy Sci. 72:68-78.

Etherington, W. G., K. A. Christie, J. S. Walton, K. E. Leslie, S. Wickstrom, and W. H. Johnson. 1991. Progesterone profiles in postpartum Holstein dairy cows as an aid in the study of retained fetal membranes, pyometra and anestrus. Theriogenology 35:731-746.

Fonseca, F. A., J. H. Britt, B. T. McDaniel, J. C. Wilk, and A. H. Rakes. 1983. Reproductive traits of Holsteins and Jerseys: Effects of age, milk yield, and clinical abnormalities on involution of cervix and uterus, ovulation, estrous cycles, detection of estrus, conception rate, and days open. J. Dairy Sci. 66:1128-1147.

Galindo, F., and D. Broom. 2002. The effects of lameness on social and individual behavior in dairy cows. J. Appl. Anim. Welf. Sci. 5:193-201.

Green, L. E., V. J. Hedges, Y. H. Schukken, R. W. Blowey, and A. J. Packington. 2002. The impact of clinical lameness on the milk yield of dairy cows. J. Dairy Sci. 85:2250-2256.

Hassall, S. A., W. R. Ward, and R. D. Murray. 1993. Effects of lameness on the behaviour of cows during the summer. Vet. Rec. 132:578-580.

Hernandez, J., J. K. Shearer, and J. B. Elliott. 1999. Comparison of topical application of oxytetracycline and four nonantibiotic solutions for treatment of papillomatous digital dermatitis in dairy cows. JAVMA 214:688-690.

Hernandez, J., and J. K. Shearer. 2000. Efficacy of oxytetracycline for treatment of papillomatous digital dermatitis lesions on various anatomic locations in dairy cows. JAVMA 216:1288-1290.

Hernandez, J., J. K. Shearer, and D. W. Webb. 2001. Effect of lameness on the calving-to-conception interval in dairy cows. JAVMA 218:1611-1614.

Hernandez, J., J. K. Shearer, and D. W. Webb. 2002. Effect of lameness on milk yield in dairy cows. JAVMA 220:640-644.

Humboldt, P., and M. Thibier. 1980. Progesterone monitoring of anestrous dairy cows and subsequent treatment with Prostaglandin $\mathrm{F}_{2 \alpha}$ analog or Gonadotropin-Releasing hormone. Am. J. Vet. Res. 41:1762-1766.

Jonsson, N. N., M. R. McGowan, K. McGuigan, T. M. Davison, A. M. Hussain, M. Kafi, and A. Matschoss. 1997. Relationships among calving season, heat load, energy balance and postpartum ovulation of dairy cows in a subtropical environment. Anim. Reprod. Sci. 47:315-326.

Lee, L. A., J. D. Ferguson, and D. T. Galligan. 1989. Effect of disease on days open assessed by survival analysis. J. Dairy Sci. 72:1020-1026.

Lucey, S., G. J. Rowlands, and A. M. Russell. 1986. The associations between lameness and fertility in dairy cows. Vet. Rec. 118:628-631.

Lucy, M. C., C. R. Staples, F. M. Michel, and W. W. Thatcher. 1991. Energy balance and size and number of ovarian follicles detected by ultrasonography in early post partum dairy cows. J. Dairy Sci. 74:473-482.
Lucy, M. C., C. R. Staples, W. W. Thatcher, P. S. Erickson, R. M. Cleale, J. L. Firkins, J. H. Clark, M. R. Murphy, and B. O. Brodie. 1992. Influence of diet composition, dry-matter intake, milk production and energy balance on time of post-partum ovulation and fertility in dairy cows. Anim. Reprod. Sci. 54:323-331.

Martin, S. W., A. H. Meek, and P. Willeberg. 1987. Disease causation. Pages 121-148 in Veterinary Epidemiology. Iowa State University Press, Ames, IA.

Melendez, P., J. Bartolome, L. F. Archbald, and A. Donovan. 2003. The association between lameness, ovarian cysts and fertility in lactating dairy cows. Theriogenology 59:927-937.

Moore, D. A., S. L. Berry, M. L. Truscott, and V. Koziy. 2001. Efficacy of a nonantimicrobial cream administered topically for treatment of digital dermatitis in dairy cattle. JAVMA 219:14351438 .

Moreira, F., C. Orlandi, C. A. Risco, R. Mattos, F. Lopes, and W. W. Thatcher. 2001. Effects of presynchronization and bovine somatotropin on pregnancy rates to timed artificial insemination protocol in lactating dairy cows. J. Dairy Sci. 84:1646-1659.

Nakao, T., M. Moriyoshi, and K. Kawata. 1992. The effect of postpartum ovarian dysfunction and endometritis on subsequent reproductive performance in high and medium producing dairy cows. Theriogenology 37:341-349.

National Animal Health Monitoring System. 2002. Reference of Dairy Health and Management in the United States, \#N341.0701. US Department of Agriculture: Animal Plant Health Inspection Service, Veterinary Services, Fort Collins, $\mathrm{CO}$

Opsomer, G., M. Coryn, H. Deluyker, and A. de Kruif. 1998. An analysis of ovarian dysfunction in high yielding dairy cows after calving based on progesterone profiles. Reprod. Domest. Anim. 33:193-204.

Opsomer, G., M. Coryn, and A. de Kruif. 1999. Measurement of ovarian cyclicity in the post partum dairy cow by progesterone analysis. Reprod. Domest. Anim. 34:297-300.

Opsomer, G., Y. T. Gröhn, J. Hertl, M. Coryn, H. Deluyker, and A. de Kruif. 2000. Risk factors for postpartum ovarian dysfunction in high producing dairy cows in Belgium: A field study. Theriogenology 53:841-857.

Reist, M., A. Koller, U. Küpfer, and J. W. Blum. 2000. First ovulation and ketone body status in the early postpartum period of dairy cows. Theriogenology 54:685-701.

Savio, J. D., M. P. Boland, N. Hynes, and J. F. Roche. 1990. Resumption of follicular activity in the early post-partum period of dairy cows. J. Reprod. Fertil. 88:569-579.

Shearer, J. K., and J. B. Elliott. 1998. Papillomatous digital dermatitis: treatment and control strategies-Part I. Compend. Contin. Educ. Pract. Vet. 20:S158-S166.

Shearer, J. K., J. Hernandez, and J. B. Elliott. 1998. Papillomatous digital dermatitis: treatment and control strategies-Part II. Compend. Contin. Educ. Pract. Vet. 20:S213-S223.

Shearer, J. K., and S. R. van Amstel. 2001. Functional and corrective claw trimming. Pages 53-72 in: The Veterinary Clinics of North America. D. A. Anderson, ed. WB Saunders Co., Philadelphia, PA

Sprecher, D. J., D. E. Hostetler, and J. B. Kaneene. 1997. A lameness scoring system that uses posture and gait to predict dairy cattle reproductive performance. Theriogenology 47:1179-1187.

Staples, C. R., W. W. Thatcher, and J. H. Clark. 1990. Relationship between ovarian activity and energy status during the early postpartum period of high producing dairy cows. J. Dairy Sci. 73:938-947.

Stevenson, J. S., and J. H. Britt. 1979. Relationships among luteinizing hormone, estradiol, progesterone, glucocorticoids, milk yield, body weight, and postpartum ovarian activity in Holstein cows. J. Anim. Sci. 48:570-577.

Stevenson, J. S., and E. P. Call. 1983. Influence of early estrus, ovulation, and insemination on fertility in postpartum Holstein cows. Theriogenology 19:367-375. 
Thatcher, W. W., and C. J. Wilcox. 1973. Postpartum estrus as an indicator of reproductive status in the dairy cow. J. Dairy Sci. 59:608-610.

Toussaint-Raven, E., R. T. Haalstra, and D. J. Peterse. 1985. Cattle Footcare and Claw Trimming. Farming Press, Ipswich, UK.

Van Arendonk, J. A. M., P. E. Stokvisch, and S. Korver. 1984. Factors determining the carcass value of culled dairy cows. Livest. Prod. Sci. 11:391-400.
Warnick, L. D., D. Jansen, and C. L. Guard. 2001. The effect of lameness on milk production in dairy cows. J. Dairy Sci. 84:1988-1997.

Wilcox, C. J., W. W. Thatcher, and F. G. Martin. 1990. Statistical analysis of repeated measurements in physiology experiments. Proc. Final Res. Coord. Mtg. FAO/IAEA/Arreglos Regionales CoOperativas para la promocion de la Ciencia y la Tecnologia Nucleares en America Latina III, International Atomic Energy Agency, Vienna, Austria (Abstr.):92. 